\title{
FALSE PREGNANCY
}

C. García Montero ${ }^{1}$, A. Duque Domínguez ${ }^{1}$, M. Mejia Quiterio ${ }^{1}$, M. Palomo Monge², R. Duque Domínguez ${ }^{3}$, A. Mas Villaseñor ${ }^{1}$, J. Ruíz Navarro ${ }^{1}$, C. Fernández Muñiz ${ }^{1}$, F. De La Torre Brasas ${ }^{1}$, N. Echeverría Hernández ${ }^{1}$, A. Sánchez García ${ }^{1}$, M. Martín Román ${ }^{1}$, M. Sánchez Losada ${ }^{4}$, D. Guerro Prado ${ }^{1}$. ${ }^{1}$ Psiquiatra, Complejo Asistencial de Ávila, Ávila, Spain. ${ }^{2}$ Psiquiatra, Hospital Nuestra Señora del Prado, Talavera de la Reina, Spain. ${ }^{3}$ Psiquiatra, Hospital Universitario de Fuenlabrada, Fuenlabrada, Spain. ${ }^{4}$ Psicólogo Clínico, Complejo Asistencial de Ávila, Ávila, Spain.

\section{OBJECTIVES}

We want to expose the main characteristics of patients diagnosed with Somatic Delirious Disorder and the main therapeutic difficulties encountered in the approach of these patients.

We present the case of a patient diagnosed with Paranoid Schizophrenia who believes she is pregnant.

\section{MATERIALS AND METHODS}

Review of clinical history and scientific literature.

\section{RESULTS}

Woman of 49 years, mother of 3 children. At the moment in separation proceedings. He has studied a module of Professional Training of Clinic Assistant. At the moment in a situation of work stoppage.

Organic antecedents: Hypothyroidism; Chronic back pain.

Psychiatric antecedents: Initiates follow-up in mental health consultations at the age of 19, diagnosed with Paranoid Schizophrenia. Abandons the monitoring and psychopharmacological treatment on several occasions. A previous admission in the Acute Unit of Psychiatry. Psychiatric family history: Elderly child diagnosed with Borderline Personality Disorder and Harmful Toxic Consumption.

Current treatment: Desvenlafaxine $100 \mathrm{mg}$ at breakfast and Eutirox 125 mg at breakfast.

Denies alcohol or other toxic consumption.

Patient referred to the emergency service for psychiatric assessment by their Primary Care Physician for presenting the idea of "being pregnant". The patient claims to be pregnant, have symptoms compatible with pregnancy such as abdominal discomfort, two months of amenorrhea and breast enlargement. Up to 10 negative pregnancy tests have been carried out, both at home and at the health center. She has also undergone a vaginal ultrasound, ruling out pregnancy as well. Even so, she is convinced that she is pregnant and for that reason she has abandoned the antipsychotic treatment that she had prescribed.

Psychopathological exploration at admission: Conscious and oriented patient in the 3 spheres. Attentive, calm and collaborative. No psychomotor restlessness or anxious symptoms. Euthymic Spontaneous speech, coherent and well structured. Delirious ideation of somatic type. Hallucinations of the kinesthetic type. Insomnia of mixed characteristics. No alteration of appetite. Not self or heteroaggressive. No ideas of death or structured autolytic plan. No awareness of illness.

Complementary explorations:

- Systematic blood and biochemistry within normality.

- Determination of thyroid hormones: within normality.

- Determination of vitamins: within normality.

- Systematic urine: normal.

- Viral and bacterial serology: negative.

- E.K.G: sinus rhythm without alterations in repolarization.

- Brain CT: No evidence of alterations in brain and cerebellar parenchymal density, or mass effects. Normal size ventricular system. Middle line not deviated. Turkish chair of normal size with pituitary gland of small size housed inside. Conclusion: No significant alterations.
Evolution: During his stay in the unit, the patient adapts normally, records the rules and maintains a cordial treatment both with the workers and with the rest of the colleagues. The delirious ideas of pregnancy in the first days of admission, somatizing the symptoms of pregnancy: abdominal distension, nausea and pigmentation of the aureoles of the nipples. Interconsultation was requested to Gynecology service due to occasional metrorrhagia. Take an anatomopathological sample with results of endocervical tissue, necrosis, inflammation and hemorrhage that were improved with blasto-stimulin ovules. The oral antipsychotic that had been abandoned with the intention of using it in its intramuscular form to reinforce therapeutic compliance was reintroduced. In this way it improved the delirious symptomatology in a remarkable way. The high, adequate and correct. There is no evidence of alteration in the major sensoperceptive sphere or anxiety. It maintained the circadian rhythms. Coherent language, well structured that does not translate alterations in the content or in the form of thought. There are no ideas of death with realistic and coherent plans of the future. Partial awareness of disease.

Diagnosis:

- 297.1 (F22) Delirious disorder somatic type.

- 295.90 (F20.9) Schizophrenia (previous).

- Possible necrotized endocervical polyp.

Treatment:

- Aripiprazole $300 \mathrm{mg}$ a monthly intramuscular ampoule.

- Lormetazepam 2 me before bedtime.

- You will go to the mental health consultation with your psychiatrist.

- Request appointment in Gynecology for follow-up.

\section{CONCLUSIONS}

Pseudociesis, also known as false pregnancy is a rare syndrome in which a woman, who is not pregnant, not only believes that she is expecting a baby but also happens to present typical symptoms of a pregnancy, including absence of menstruation and increase in volume abdominal.

Psychological pregnancy is a condition that affects women of all ethnic groups, regions and social classes. It is more common in married women and with ages between 20 and 40 years, but there are cases described in children and older women, even after menopause.

Pseudocytosis seems to occur due to neuroendocrine system stimuli caused by psychological factors.

Studies show that rather than treating psychological pregnancy, the personality disorder must be treated so that the symptom stops appearing. That is, pseudocytosis is seen as the end of a long anxiety or depression disorder.

\section{BIBLIOGRAPHIC REFERENCES}

1. Kaplan HI, Sadock BJ. Sinopsis de Psiquiatría. 10a ed. Barcelona: Wolters Kluwer; 2009.

2. Vallejo Ruiloba J., Leal Cercós C. Tratado de Psiquiatría. Madrid: Marbán; 2012

3. Palomo T., Jiménez-Arriero M.A. Manual de Psiquiatría. Madrid: Grupo ENE Publicidad, S.A

4. APA, DSM-5 Manual diagnóstico y estadístico de los trastornos mentales. 5ạed. Madrid: Panamericana; 2014.

5. CIE 10. Décima revisión de la clasificación internacional de las enfermedades. Trastornos mentales y del comportamiento. Publicado por la OMS en Ed Meditar (Madrid). Ginebra 1992. 